

\section{Sumário}

Dossiê TEMÁTICO: NOVOS INSTITUTOS JURÍDICOS DE LICITAÇÕES E CONTRATOS 17

I. LicitaÇõEs E CONTRATOS PÚBLICOS: PARTE GERAL. 18

INTEGRATED CONTRACT IN LAW 14.133/2021: NEW LAW, SAME PROBLEMS? A STUDY OF COMPARATIVE LAW .20

Paulo Afonso Cavichioli Carmona, Bruno Ribeiro Marques e Odilon Cavallari

Reajustamento de preços na Nova Lei de Licitações e Contratos Administrativos BRASILEIRA: O "Princípio" Da ANUALIDAde.

Ricardo Silveira Ribeiro e Bráulio Gomes Mendes Diniz

A nova Lei de Licitações, as encomendas tecnológicas e o diálogo competitivo .61 André Dias Fernandes e Débora de Oliveira Coutinho

LiCITAÇÕES, CONTRATOS E O IMPULSO À APRENDIZAGEM PROFISSIONAL: UM ESTUDO SOBRE A CONTRATAÇÃo de APRENDizes no ESTAdo do AMAZONAS, BRAsIL

Emerson Victor Hugo Costa de Sá, Natasha Yasmine Castelo Branco Donadon e Mauro Augusto Ponce de Leão Braga

Licitações, contratos e Modelo Brasileiro de Processo: notas sobre a viabilidade DA UTILIZAÇÃo DE FERRAMENTAS PROCESSUAIS PARA CONFERIR MAIOR EFICIÊNCIA ÀS AQUISIÇÕES PÚBLICAS

Claudio Madureira e Carlos André Luís Araujo

RESOlUÇão DE CONFLITOS COM A ADMINISTRAÇÃo PÚBLICA E A NOVA LEI DE LICITAÇÕES E CONTRATOS: REFORÇO DOS MEIOS ALTERNATIVOS..

Clarissa Sampaio Silva e Danielle Maia Cruz

A Adesão do Brasil ao Acordo sobre Contratações Públicas da OMC: entre tabus e DIFICULDADES REAIS.

Eduardo Ferreira Jordão e Luiz Filippe Esteves Cunha

II. Accountability e controle

A LEI N. ${ }^{\circ}$ 14.133/2021 E OS NOVOS LIMITES do CONTROLE EXTERNO: A NECESSÁRIA DEFERÊNCIA dos Tribunais de Contas em prol da Administração Pública .................................. 162 Ricardo Schneider Rodrigues

O CONTROLE DAS CONTRATAÇÕES PÚBliCAS E A NOVA LEI DE LICITAÇÕES: O QUE HÁ DE Novo? 183

Leandro Sarai, Flávio Garcia Cabral e Cristiane Rodrigues Iwakura 
Programa de compliance como exigênCia em licitações: ANálises EM Prol da QUALIFICAÇÃo DO PROCESSO LICITATÓRIO NO CONTEXTO DA LEI 14.133/2021.

Cristian Ricardo Wittmann e Anayara Fantinel Pedroso

A NOVA REALIDAde bRASILEIRA DE NECESSIDADE DE PROGRAMAS DE INTEGRIDADE DAS PESSOAS JURÍDICAS LICITANTES EM PROCESSOS LICITATÓRIOS DA ADMINISTRAÇÃO PÚBLICA 227

Fernando Silva Moreira dos Santos e Luiz Fernando de Oriani e Paulillo

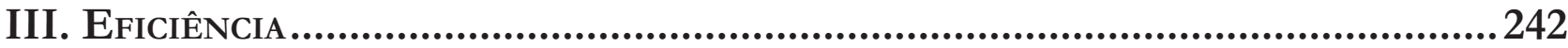

Efficiency contracts in the New Brazilian Procurement Law: conceptual FRAMEWORK AND INTERNATIONAL EXPERIENCE

Floriano de Azevedo Marques Neto, Hendrick Pinheiro e Tamara Cukiert

A gestão de riscos como instrumento para a aplicação efetiva do Princípio Constitucional dA EFICIÊNCIA.

Rafael Rabelo Nunes, Marcela Teixeira Batista Sidrim Perini e Inácio Emiliano Melo Mourão Pinto

IV. Contratação PÚblica No Direito ESTrangeiro

LA ADQUisición de VACUNAS CONTRA LA COVID-19 POR COLOMBIA: ENTRE LA CONFIDENCIALIDAD Y LA FALTA DE TRANSPARENCIA. 284

Gressy Kareny Rojas Cardona e David Mendieta

LA DISCRIMINACIÓN EX POST DE LOS OFERENTES DE UNA LICITACIÓN PÚBLICA COMO INFRACCIÓN ADMINISTRATIVA Y DE LIBRE COMPETÊNCIA 312 Jaime Arancibia Mattar

LA DISCRIMINACIÓN EX POST DE LOS OFERENTES DE UNA LICITACIÓN PÚBLICA COMO INFRACCIÓN ADMINISTRATIVA Y DE LIBRE COMPETÊNCIA..........................................................332 Udochukwu Uneke Alo, Obiamaka Adaeze Nwobu e Alex Adegboye

Outros Temas 348

I. Políticas públicas e institucionalidade

¿Existe El derecho humano a la identidad Cultural de los Migrantes en El Derecho INTERNACIONAL? 351

Glorimar Alejandra Leon Silva e Juan Jorge Faundes

El acceso a la justicia y el debido proceso ante el Tribunal Constitucional y la CorTe Suprema: dos NOCIONES DEL CONTENCIOSO ADMINISTRATIVO CHILENO .384 Pedro Harris Moya 
“Ministrocracia” E DECISÕES INDIVIDUAis CONTRAditórias No Supremo Tribunal FEDERAI

Ulisses Levy Silvério dos Reis e Emilio Peluso Neder Meyer

A POlÍtica de INOVAÇÃo COMO INSTRUMENTO DE REDUÇÃo DAS DESIGUALDADES REGIONAIS NO BRASIL

Caroline Viriato Memória e Uinie Caminha

Conflitos de Competência E A JudicializaÇão da Saúde no Federalismo Brasileiro.447 Jorge Leal Hanai, Luis Antônio Abrantes e Luiz Ismael Pereira

O Ministério Público no enfrentamento dos Reflexos da CRise da Covid-19: UMA

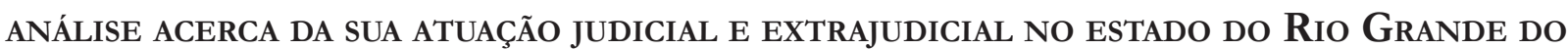
NorTE

Raquel Maria da Costa Silveira, Ana Mônica Medeiros Ferreira, Flávio Luiz Carneiro Cavalcanti e Haroldo Helinski Holanda

A CONSAgRaÇão CONSTITUCIONAL DA POlítica FALIMENTAR

Nuno de Oliveira Fernandes

II. Políticas públicas, grupos vulneráveis e litígios estruturais

LAS LIMITACIONES A LOS DERECHOS DE LOS GRUPOS VULNERABLES Y LOS SUJETOS DE ESPECIAL PROTECCIÓN DURANTE LA PANDEMIA Mary Luz Tobón Tobón

LitígIOS ESTRUTURAIS E A PROTEÇÃO DOS DIREITOS DOS POVOS INDÍGENAS DURANTE A PANDEMIA DE Covid-19: CONTRIBUições do ICCAL

Ana Carolina Lopes Olsen e Bianca M. Schneider van der Broocke

EPISTEMICÍDIO DAS NARRATIVAS NEGRAS E LITÍGIO ESTRUTURAL: INSTRUMENTOS EXTRAJUDICIAIS PARA DISSOLUÇÃO DO PROBLEMA NO SISTEMA EDUCACIONAL .......................................582

Vitor Fonsêca e Caroline da Silva Soares

Trajetórias E DiRETRIZES dAS POlíticas PÚbliCAS NACIONAIS PARA A POPULAÇão INFANTOJUVENIL EM SITUAÇÃO DE RUA...

Wânia Cláudia Gomes Di Lorenzo Lima, Cynthia Xavier de Carvalho e Maria Creusa de A. Borges

Emprendimiento como Fuente de Ingresos para las Víctimas del Conflicto Armado en el Marco de la Ley 1448 de Colombia. Reflexiones de la Implementación en el Valle del Cauca

Saulo Bravo García e Luz Marina Restrepo García

III. Políticas públicas e aÇão Restaurativa. 
JUSTIÇA RESTAURATIVA COMO AÇÃO COMUNICATIVA: EQUILÍBRIO ENTRE SISTEMA E MUNDO DA

Daniela Carvalho Almeida da Costa e Luciana Leonardo Ribeiro Silva de Araújo

JUSTIÇA RESTAURATIVA: ACORDOS E COOPERAÇÃO.................................................668

Samyle Regina Matos Oliveira e Selma Pereira de Santana 


\title{
Programa de compliance como exigência em licitações: análises em prol da qualificação do processo licitatório no contexto da lei $14.133 / 2021^{*}$
}

\author{
Compliance Program as a requirement in \\ governmental purchases: observations to \\ qualify the Brazilian bidding process under Law \\ $14.133 / 2021$
}

\author{
Cristian Ricardo Wittmann** \\ Anayara Fantinel Pedroso***
}

\section{Resumo}

Este estudo visa analisar os aspectos relativos à exigência de adoção de um programa de compliance anticorrupção nas organizações licitantes enquanto possível qualificadora do processo licitatório, a fim de diminuir práticas relacionadas à improbidade administrativa quando da contratação pública. Para tanto analisa-se o programa de compliance e a aplicação no setor público; as normas relacionadas à licitação e em quais etapas podem ser instituídos novos mecanismos de controle, além de identificar os principais benefícios da implementação dessa política por empresas na participação de processos licitatórios. Como resultado, identifica-se a importância da utilização da ferramenta para auxiliar o combate às práticas de improbidade administrativa, uma vez que objetiva não apenas responsabilizar atos ímprobos, mas também evitá-los a partir de uma gestão de riscos. Aborda-se o benefício às organizações de tais programas, fomentando uma cultura empresarial delimitada por padrões éticos e morais, garantindo que as normas sejam cumpridas, qualificando a segurança nas contratações realizadas no âmbito empresarial, corroborando menores desvios corruptivos, fomentando uma sinergia entre os deveres da Administração Pública e os anseios da sociedade. Verifica-se a necessidade de constatar qual o momento oportuno que deva ser exigido o compliance nos certames. Se exigido no momento do julgamento, torna-se contrário aos princípios licitatórios, uma vez que limitaria a concorrência. Supõe-se que essa exigência seja mais eficaz se cobrada na fase de contratação com o erário. Diante do exposto, a fim de garantir a efetivação dos objetivos, utiliza-se o método de abordagem qualitativo de natureza básica, exploratória e de procedimento bibliográfico dedutivo.

Palavras-Chave: compliance; Administração Pública; corrupção; licitação.

*** Mestranda no Programa de Pós-Graduação em Direito e Justiça Social da Universidade Federal do Rio Grande (PPGDJS/FURG). Advogada. Bacharela em Direito pela Universidade Federal do Pampa (Unipampa). Lattes: http://lattes. cnpq.br/4931636737843628

E-mail: anayarafantinelpedroso@gmail.com 


\section{Abstract}

This paper aims to contribute with the aspects related to the requirement to adopt an anti-corruption compliance program in bidding organizations as a possible way to qualify the process to reduce practices described as administrative misconduct in public procurement. For that, the compliance program and the application in the public sector are analyzed; norms related to bidding and in what stages of such process new control mechanisms can be instituted to reduce corruptive practices, in addition to identifying the main benefits of implementing an anti-corruption compliance policy by companies when participating in bidding processes. As a result of this research, it was determined the importance of using the tool to help combat administrative misconduct practices since it aims to make unlawful acts accountable and avoid them through risk management. The benefit to organizations of such programs is addressed, fostering a business culture delimited by ethical and moral standards, ensuring that the rules are complied with by all. It will also qualify security in business contracts, supporting less corruptive deviations, fostering a synergy between the duties of the Public Administration and the concerns of society. There is a need to verify the opportune moment that compliance should be required in biddings. If necessary, it is contrary to the precepts of competition at the time of judgment. When considering the bidding's normative principles, it is assumed that this requirement is more effective if charged in the contracting phase with the Administration. The qualitative approach method of a primary, exploratory, and deductive bibliographic procedure is used to ensure the achievement of objectives.

Keywords: compliance; Public Management; corruption; bidding.

\section{Introdução}

A corrupção é considerada um problema sistêmico, que desgasta as instituições e impõe óbices à efetivação dos direitos difusos e garantias individuais, afetando, diretamente, o bem-estar da população, a economia Nacional, Internacional e, consequentemente, o desenvolvimento do Estado e os pilares básicos da acepção democrática do Estado de Direito. Diante disso, o combate à corrupção, bem como a prevenção desta são questões de interesse coletivo. Pois, na medida em que esses ilícitos aumentam, inversamente proporcional têm-se investimentos sociais e isso, consequentemente, traz inúmeros prejuízos para a sociedade como um todo. Dessa forma, torna-se um imperativo aperfeiçoar os sistemas de controle públicos e privados.

Por serem pontos de grande quantidade de fluxos financeiros e de atividades entre o setor público e o privado, os processos licitatórios e, consequentemente, as contratações públicas são um relevante ponto de alerta no combate à corrupção. Nesse sentido, verifica-se a necessidade de adoção de programas que qualifiquem o processo licitatório, como as políticas de integridade.

Diante desse quadro, o presente trabalho visa analisar de que maneira a obrigatoriedade de um programa de compliance anticorrupção, para contratar com a administração pública, poderá qualificar o processo licitatório, buscando, para isso, uma maior compreensão desse programa e da respectiva aplicação nas instituições.

Verifica-se a necessidade da qualificação do processo licitatório, uma vez que, a partir desse procedimento, será escolhida a empresa que irá contratará com a Administração Pública, impactando, diretamente, os atos desta na forma como serão geridos os direitos sociais além de, consequentemente, estar relacionada à qualidade da prestação do serviço público em voga. Portanto, é relevante a exigência de alguns quesitos por parte da Administração Pública de maneira que sejam expandidos os instrumentos capazes de garantir a transparência e a integridade nas empresas contratantes, bem como efetivar os princípios inerentes ao processo licitatório como a legalidade, a impessoalidade, a moralidade, a publicidade e a probidade administrati- 
va. Dessa forma, surge o questionamento: de que maneira a obrigatoriedade de um programa de compliance $e^{1}$ anticorrupção nas empresas licitantes pode qualificar o processo licitatório?

Procura-se, com base no presente trabalho, associar a temática do compliance — que se encontra em voga no mundo corporativo devido ao fato de aproximar a gestão dos níveis de conformidade —, à eficácia da exigência dos programas de integridade ${ }^{2}$ por parte da Administração Pública para com as empresas que com ela contratarão, como forma de qualificar o processo licitatório. Contudo, cautelas são necessárias para que essa exigência não tenha como consequência a própria ruína dos certames, ao invés de somente qualificar, pode gerar uma maior restrição aos licitantes. Pois, uma limitação demasiada tende a uma maior desvantagem ao Estado no momento da contratação, o que prejudicaria o desenvolvimento sustentável do País.

Urge (re)discutir o processo licitatório como um todo, por meio de novas perspectivas no tocante à necessidade da adoção dos programas de integridade. Para isso, objetiva-se analisar os aspectos relativos à exigência de adoção de um programa de compliance anticorrupção nas empresas licitantes enquanto possível qualificadora do processo licitatório a fim de diminuir práticas ilegais relativas à contratação pública; compreender o programa de compliance e a aplicação nas instituições; analisar as legislações relacionadas à licitação e em quais etapas podem ser instituídos novos mecanismos de controle visando à diminuição das práticas corruptivas, além de identificar os principais benefícios da implementação de uma política de compliance anticorrupção por empresas quando da sua participação em processos licitatórios.

A fim de atingir os objetivos traçados e responder os questionamentos, em um primeiro momento, faz-se necessário compreender a evolução do programa de compliance anticorrupção, para defini-lo e compreender a respectiva aplicação nas instituições. A partir de então, serão analisados os desmembramentos dos setores específicos dessa política, correlacionados com as respectivas áreas de atuação, para, em um momento oportuno, analisar-se o processo licitatório como um todo, sobretudo no que tange aos princípios da licitação e fases procedimentais, para enfim, concluir qual o momento oportuno para a exigência de um programa de compliance. Por fim, serão analisados os benefícios e dificuldades visualizadas em relação à implementação desse programa.

Para a realização deste estudo, utiliza-se do método de abordagem qualitativo, de natureza básica, exploratória e de procedimento bibliográfico-dedutivo, a fim de se analisarem as questões mais generalistas, em um primeiro momento, no que tange ao compliance e à aplicação nas empresas; as legislações que estimulam a criação de programas que visem diminuir as práticas de improbidade administrativa, bem como as questões pormenorizadas do programa de compliance, especialmente no que tange à aplicabilidade nas empresas e na participação do processo licitatório. Obtendo subsídios para posteriori, buscar uma análise mais específica,

\footnotetext{
1 O termo Compliance é de origem anglo-saxônica e significa agir em conformidade com alguma regra, com algum ordenamento, seja ele interno ou externo. Tem origem no verbo inglês "to comply", significando cumprir, concordar, obedecer, consentir, aquiescer. Ou seja, é a obrigação de agir de acordo com as diretrizes éticas estipuladas, sob pena de possíveis sanções, previamente estabelecidas, conforme leciona MOREIRA, Eliane de Oliveira. Compliance no Brasil: Aspectos da responsabilidade fiscal das empresas no combate à corrupção. Paraná: Revista Jurídica da Escola Superior de Advocacia da OAB-PR, 2018, n. 3. Acesso em: 27 jul. 2021.

2 Embora existam diferenças — por mínimas que sejam - conceituais, no que tange aos termos "programas de compliance” e "programas de integridade", acredita-se, diante do campo de atuação prático-institucional, que esses programas se tornam modelos que se confundem, uma vez que atuam na mesma direção, buscando os mesmos objetivos e utilizando-se dos mesmos mecanismos para atingi-los, obstinados na busca de um fim comum: estar em conformidade com os ordenamentos, garantindo, sobretudo, a integridade empresarial. Nesse sentido, diversos autores corroboram com a similitude conceitual, afirmando que há diferenças mínimas no que tange aos termos "compliance" e "programa de integridade", pois possuem objetivos em comuns. Portanto, não havendo ainda grandes divergências doutrinárias quanto às denominações, utiliza-se, neste artigo, os termos "programas de integridade" e "compliance" como sinônimos. Conforme menciona, a título exemplificativo, SCHRAMM Fernanda Santos. O compliance como instrumento de combate à corrupção no âmbito das contratações pública. 2018, p. 245. Disponível em: https://repositorio.ufsc.br/handle/123456789/190091 Acesso em: 27 jul. 2021: “A Lei Federal n. ${ }^{\circ}$ 12.846/2013 e o Decreto n. ${ }^{\circ}$ 8.420/2015 não usam o termo programa de compliance, mas, sim, programa de integridade. Entretanto, considerando-se a inexistência de conceito unívoco no ordenamento jurídico e na doutrina nacional — o que se extrai da Lei Federal n. ${ }^{\circ}$ 13.303/2016, que usa o termo compliance para referir-se ao programa de integridade". Dessa mesma forma, a nova lei de licitações, também, utiliza o termo "programa de integridade" e, diante do exposto, no presente estudo, será utilizado enquanto sinônimo do termo compliance.
} 
a fim de exaurir as questões acerca da exigência do compliance anticorrupção no processo licitatório como forma de qualificação deste.

\section{A aplicação do programa de compliance anticorrupção como forma de prevenção de riscos e consolidação da probidade corporativa}

O programa de compliance diz respeito à conformidade da organização a um arcabouço de normas. Esse inclui a legislação Estatal, bem como a observância de preceitos morais de honestidade e transparência, não apenas na maneira de conduzir os negócios, mas em todas as atitudes comportamentais dos membros de uma instituição - avançando em muitos casos para questões trabalhistas, ambientais, saúde do trabalhador dentre outras. Observa-se que essa política de compliance pode ser vista como uma estratégia de prevenção ou até mesmo minimização dos possíveis riscos organizacionais, uma vez que se dá por meio de uma programação de normativas que devam ser seguidas por todos os que a ela estão subordinados ${ }^{3}$. Implementar um programa desses passa a ser um investimento, antecipando riscos e alinhando continuamente as ações da organização aos seus objetivos estratégicos ${ }^{4}$.

Isso porque caracteriza-se enquanto uma importante ferramenta para o combate às práticas de improbidade administrativa, uma vez que, a partir do enquadramento, enquanto um sub ordenamento jurídic ${ }^{5}$, possui a capacidade não apenas de responsabilização das possíveis práticas ímprobas, diminuindo os riscos proporcionados por essas por meio do aumento da fiscalização e aplicação dos códigos de conduta das organizações — sejam elas públicas ou privadas.

A política de Compliance visa aquiescer às limitações que são colocadas pelo sub ordenamento jurídico ${ }^{6}$, por meio da instauração de códigos de conduta de âmbito interno, destinando-se à mitigação de práticas ilícitas e contrárias aos objetivos institucionais por meio da construção de uma cultura organizacional delimitada por padrões éticos que mantenham a integridade 7 . Um programa voltado a preceitos anticorrupção, por exemplo, caminha de encontro com os princípios constitucionais estabelecidos na Carta Magna, no artigo $37^{8}$, como moralidade administrativa, eficiência, legalidade, publicidade e impessoalidade 9

Em suma, a política de compliance visa a uma prevenção ou até mesmo atenuação dos possíveis riscos decorrentes do descumprimento de determinadas normativas por atos ilícitos praticados tanto pelos agentes econômicos quanto pelos demais colaboradores da instituição em voga. Para isso, é extremamente impor-

\footnotetext{
3 MOREIRA, Eliane de Oliveira. Compliance no Brasil: Aspectos da responsabilidade fiscal das empresas no combate à corrupção. Revista Jurídica da Escola Superior de Advocacia da OAB-PR, n. 2. Disponível em: http://revistajuridica.esa.oabpr.org.br/wpcontent/ uploads/2018/09/revista_esa_7_14.pdf Acesso em: 27 jul. 2021.

4 Cf. GARBACCIO, Grace Ladeira; et al. Startup e o desafio do compliance. Revista Brasileira de Políticas Públicas, Brasília, volume 10, n. 3, dez 2020, pp 329-342.

5 WITTMANN, Cristian Ricardo. Programas de cumprimento (Compliance Programs) e o Direito na sociedade global: A concepção de um campo autônomo de regulação das nanotecnologias em usos militares. Tese: Programa de Pós-Graduação Em Direito - Doutorado Linha De Pesquisa: Sociedade, Novos Direitos E Transnacionalização, São Leopoldo, 2015. Disponível em: http://www.repositorio. jesuita.org.br/handle/UNISINOS/6257 Acesso em: 12 jul. 2021.

${ }^{6}$ WITTMANN, Cristian Ricardo. Programas de cumprimento (Compliance Programs) e o Direito na sociedade global: A concepção de um campo autônomo de regulação das nanotecnologias em usos militares. Tese: Programa de Pós-Graduação Em Direito - Doutorado Linha De Pesquisa: Sociedade, Novos Direitos E Transnacionalização, São Leopoldo, 2015. Disponível em: http://www.repositorio. jesuita.org.br/handle/UNISINOS/6257 Acesso em: 12 jul. 2021.

8 "Art. 37. A administração pública direta e indireta de qualquer dos Poderes da União, dos Estados, do Distrito Federal e dos Municípios obedecerá aos princípios de legalidade, impessoalidade, moralidade, publicidade e eficiência”. BRASIL. Constituição (1988). Constituição da República Federativa do Brasil. Disponível em: http://www.planalto.gov.br/ccivil_03/constituicao/constituicaocompilado.htm. Acesso em: 12 out. 2019.

9 SCHRAMM Fernanda Santos. O compliance como instrumento de combate à corrupção no âmbito das contratações pública. 2018. Disponível em: https://repositorio.ufsc.br/handle/123456789/190091 Acesso em: 27 jul. 2021.
} 
tante a implementação de uma cultura de conformidade, de forma a tornar habitual e intrínseca aos agentes relacionados com a instituição a prática de atos pautados pela honestidade. Demonstrando, assim, o compromisso destes com os valores e objetivos institucionais ditados pela própria política de compliance, visando ao cumprimento permanente das normativas estabelecidas. Nesse sentido, um programa de conformidade abarca uma série de setores, dividindo-se em compliance anticorrupção - que será abordado no presente estudo; fiscal; ambiental; trabalhista; governança; criminal, dentre outros, podendo encontrarem-se de maneira unificada ou até mesmo separadamente ${ }^{10}$.

Esse programa de controle interno é capaz de promover segurança às transações comerciais, especialmente no que tange à orientação dos negócios por meio de análises econômico-financeiras. Buscando, assim, uma gestão empresarial eficiente, capaz prevenir questões como fraudes, além de elaborar e garantir que as normativas sejam cumpridas por todos os membros da instituição ${ }^{11}$. Aspirando alcançar, mormente, a consolidação dos mecanismos de controle internos dentro das organizações, mitigando e prevenindo os riscos e, principalmente, contribuindo para a criação de uma cultura empresarial calcada na ética. Ainda, é um programa capaz de promover, também, a segurança ao público no qual as próprias organizações estão direcionadas e demais colaboradores, atingindo, assim, a sociedade como um todo e consequentemente, o mercado de capitais.

Os primeiros programas de compliance foram constituídos em bases principiológicas voltadas ao reconhecimento de um grau de culpabilidade das empresas em decorrência de possíveis atos ilícitos praticados pelos membros destas, bem como ao estímulo à adoção de comportamentos organizacionais desejados, visando atender às limitações exigidas pelos ordenamentos jurídicos vigentes, utilizando-se da criação de códigos internos ambicionando a diminuição da possibilidade dos riscos empresariais. Uma vez que, com a exigência de políticas de compliance, há a consolidação de uma cultura ética organizacional com base na existência de mecanismos de controle, prevenção e sanções dos comportamentos ímprobos. Situações que possibilitam uma maior proteção aos negócios realizados no âmbito empresarial, uma vez que há uma maior transparência ${ }^{12}$.

A partir dessa capacidade de diminuição de riscos empresariais por meio da construção de uma cultura delineada em valores éticos corporativos que os programas de integridade são capazes de fornecer segurança às organizações e a todos os demais atores que com ela se relacionam, como pode-se perceber:

Na verdade, quando se fala em compliance, está-se referindo aos sistemas de controle internos que servem para proporcionar maior segurança à empresa quanto às suas análises econômico-financeiras, possibilitar uma atuação correta e adequada no meio em que atua, proteger contra os riscos de corrupção e fraudes em processos licitatórios ou demais delações com entidades governamentais, elaborar e atualizar normas internas que estejam em harmonia com a filosofia da companhia e garantir que sejam conhecidas e cumpridas por todos ${ }^{13}$.

Vale ressaltar que o compliance é utilizado de maneira ambígua. Seja como uma ferramenta de controle e prevenção interna das organizações de possíveis atos de corrupção, bem como um instrumento de transferência de responsabilidade da empresa, evitando ou até mesmo amenizando-a quando da existência desses atos, atenuando a responsabilidade objetiva da pessoa jurídica. Atualmente, ele vem sendo adotado pelas instituições com o objetivo de proteger a integridade institucional por meio da mitigação dos fatos preju-

\footnotetext{
${ }^{10}$ CONSELHO ADMINISTRATIVO DE DEFESA ECONÔMICA. Guia para Programas de Compliance. 2016. Disponível em: http://www.cade.gov.br/acesso-ainformacao/publicacoes-institucionais/guias_do_Cade/guia-compliance-versao-oficial.pdf Acesso em: 10 set. 2019.

11 COLARES, Wilde Cunha. Ética e compliance nas empresas de outsourcing. 2014. Disponível em: http://dspace.insper.edu.br/xmlui/ handle/11224/1238 Acesso em: 10 ago. 2021.

12 SCHRAMM, Fernanda Santos. O compliance como instrumento de combate à corrupção no âmbito das contratações pública. 2018. Disponível em: https://repositorio.ufsc.br/handle/123456789/190091 Acesso em: 27 jul. 2021.

13 COLARES, Wilde Cunha. Ética e compliance nas empresas de outsourcing. 2014. Disponível em: http://dspace.insper.edu.br/xmlui/ handle/11224/1238 Acesso em: 10 ago. 2021. p. 60.
} 
diciais à instituição, da conscientização dos profissionais das áreas de riscos e da preservação dos interesses dos clientes, dando mais segurança a eles e consequentemente à empresa. Mantendo assim, uma boa reputação ${ }^{14}$. Diante desse quadro de controle interno, por meio da conformidade com as leis e ordenamentos, e transparência institucional, inúmeros mecanismos, inerentes à segurança organizacional, estão intrínsecos nele como a Governança Corporativa, possibilitando uma melhor imagem da empresa que os adotam por meio de bases éticas sólidas e comprometida com os negócios ${ }^{15}$.

Embora a política de compliance possa ser aplicada em qualquer tipo de organização - uma vez que a sociedade tende a exigir condutas éticas a fim de que seja consolidada uma cultura ética empresarial — deve-se considerar que nele existem pequenas, médias e grandes instituições. E que cada uma delas necessita de um direcionamento diferente, que se desenvolva de acordo com os próprios planejamentos e valores culturais, considerando-se a trajetória percorrida, os objetivos traçados e as áreas institucionais mais frágeis que estejam à iminência dos possíveis riscos, pensando-se nessa política a partir das particularidades organizacionais. Por isso, o programa de conformidade deve ser individualizado para as organizações, devendo ser aplicado após uma análise minuciosa dos quesitos supracitados e no período de tempo necessário para uma melhor adaptação e desenvolvimento do sistema por parte da instituição, buscando, assim, a eficiência plena desse programa ${ }^{16}$.

Embora a perspectiva de regulação envolva, prioritariamente, aspectos proibitivos, relevante, também, é verificar os outros aspectos que envolvem a regulação do contexto organizacional. Historicamente, a proibição direta de condutas obteve maior atenção ampliando-se hoje a uma regulação de análise das circunstâncias favoráveis à prática delitiva, combinando aspectos de informação, treinamento, incentivos quando da prática positiva e proativa dentre outras ${ }^{17}$.

A adoção de programas de conformidade pela Administração Pública, seja ela direta ou indireta, é de extrema valia dado que oportuniza a transparência das ações institucionais, uma necessidade na atual conjuntura político-econômica. Além disso, o Erário, por meio de suas instituições, estará dotado de políticas preventivas aos riscos, fundadas em fortes bases éticas, corroborando a efetividade dos serviços prestados e, consequentemente, dando causa à construção de uma boa reputação institucional frente à sociedade como um todo. Como o compliance possui como uma das funções principais o combate às práticas ímprobas, resulta em outros benefícios decorrentes deste, como a diminuição dos processos administrativos e judiciais, diminuindo, também, os riscos empresariais e possíveis danos à reputação desta, quando bem aplicado ${ }^{18}$.

Dessa forma, a implementação de um programa de integridade deverá ser entendida como uma ferramenta crucial para adoção de uma cultura ética, instituída com base em mudanças comportamentais, estabelecendo condutas adversas à corrupção. Criando-se, assim, uma espécie de normas morais intrínsecas às pessoas que se relacionam com o grupo empresarial, e não apenas para evitar a responsabilidade da empresa quando preterida ${ }^{19}$.

\footnotetext{
${ }^{14}$ GABARDO, Emerson; CASTELLA, Gabriel Morettini. A nova lei anticorrupção e a importância do compliance para as empresas que se relacionam com a Administração Pública. A\&C-Revista de Direito Administrativo \& Constitucional, v. 15, n. 60, p. 129-147, 2015. Disponível em: http://www.revistaaec.com/index.php/revistaaec/article/view/55 Acesso em: 10 set. 2021.

15 GARCIA, Sheila Abukater Arkie. Compliance: um instrumento de governança corporativa e fomento do mercado de capitais. 2012. Disponível em: http://dspace.insper.edu.br/xmlui/handle/11224/303 Acesso em: 27 ago. 2021.

${ }_{16}$ RIBEIRO, Marcia Carla Pereira; DINIZ, Patrícia Dittrich Ferreira. COMPLIANCE E LEI ANTICORRUPÇÃO NAS EMPRESAS. Paraná: Revista de Informação Legislativa, 2015, n. 205. Disponível em: https://www12.senado.leg.br/ril/edicoes/52/205/ ril_v52_n205_p87.pdf Acesso em 20 maio 2021.

${ }^{17}$ Cf. JORDÃO, Eduardo; COSTA, Luiz Carloss Penner Rodrigues da. Estratégias regulatórias de controle à corrupção. Revista Brasileira de Políticas Públicas, Brasília, volume 11, n. 1, abr 2021, pp 210-241.

18 MINISTÉRIO DA TRANSPARÊNCIA E CONTROLADORIA-GERAL DA UNIÃO - CGU. Manual para implementação de programas de integridade - orientaçôes para o setor público. 2017. Disponível em: https://cgu.gov.br/Publicacoes/etica-e-integridade/arquivos/manual_profip.pdf Acesso em: 27 set. 2020.

19 SCHRAMM, Fernanda Santos. O compliance como instrumento de combate à corrupção no âmbito das contratações pública. 2018. Disponível em: https://repositorio.ufsc.br/handle/123456789/190091 Acesso em: 27 jul. 2021.
} 
De fato, seria preferível o estímulo de adoção de programas de integridade por meio de normas promocionais e não a imposição de implementação nesses programas para contratar com a Administração Pública. Contudo, tratando-se de uma sociedade que se encontra em uma caminhada constante para uma conduta calcada na moralidade, e ainda não a ter atingido plenamente, faz-se necessário a atuação das normas legais a fim de tornar habitual a prática de condutas probas, principalmente no que tange a fatores que se relacionam à efetivação dos direitos difusos e garantias individuais, que é o erário. Portanto, a obrigatoriedade da existência do compliance torna-se viável e congruente com o ordenamento constitucional, dado que visa resguardar os valores e princípios constitucionais e administrativos ${ }^{20}$.

Desse modo, considera-se pertinente a exigência da adoção de um programa de compliance como forma de consagração dos princípios constitucionais como a legalidade, moralidade, impessoalidade, dentre outros, constituindo dever do Estado preservá-los e exigir a preservação. Isso porque a exigência do respeito aos princípios balizadores da Administração Pública possibilita uma maior eficiência a respeito da prestação de serviços para a sociedade, especialmente se dentre as formas de exigência englobarem a adoção de políticas de integridade, que possibilitam a diminuição da prática de atos ilícitos por meio da construção de uma cultura organizacional pautada na idoneidade.

\section{A lei $.^{\circ} 14.133 / 2021$ E a possibilidade de exigência de um programa de compliance anticorrupção no processo licitatório}

Os princípios que regem a Administração Pública também constituem o processo licitatório, contudo a Nova Lei de Licitações (n. ${ }^{\circ} 14.133 / 2021$ ), no artigo $5^{\circ}$, dispõe de um rol exemplificativo que urge mencioná-los para que seja possível observar a convergência do programa de integridade com estes princípios consolidantes dos processos que envolvem o erário público.

O primeiro princípio a ser relatado trata-se do Princípio da Moralidade, que exige das partes condutas éticas, calcadas na honestidade e boa-fé, estando diretamente relacionado ao Princípio da Impessoalidade que exige que todos os possíveis contratantes sejam tratados da mesma maneira por parte daquele ${ }^{21}$. Tanto a Administração Pública quanto os licitantes devem agir de maneira proba, uma vez que a não adequação a esse princípio enquadra-se no conceito de crime, aplicando-se sanções penais, administrativas e civis. Ressalta-se que o cometimento de prática ímprobas não se dá, apenas, no momento da elaboração do instrumento convocatório por meio do favorecimento de determinadas instituições em detrimento de outras, mas também, no momento da execução contratual22. Por isso, deve ser exigida, no processo licitatório, a existência de instrumentos de controle — dentro das próprias empresas e fiscalizadas pelo Estado — que previnam, coíbam e tornem ainda mais difíceis os atos de corrupção.

O Princípio da Publicidade estabelece que todos os atos praticados pela Administração, nas fases da licitação, devem ser públicos, a fim de que possa ser fiscalizada a legalidade por todos os interessados ${ }^{23}$. Ou seja, o processo licitatório deve ser largamente publicizado, proporcionando, assim, uma maior eficiência procedimental na seleção da proposta mais vantajosa, ao passo que será amplamente conhecida essa realiza-

\footnotetext{
${ }^{20}$ COSTA, Gabriela Revoredo Pereira. Compliance, lei da empresa limpa e lei sapin II: uma análise da aplicação do regime de obrigatoriedade de adoção de programas de integridade corporativa no Brasil. 2017. Trabalho de Conclusão de Curso. Universidade Federal do Rio Grande do Norte. Disponível em: https://monografias.ufrn.br/jspui/bitstream/123456789/5659/1/GabrielaRPC_Monografia.pdf Acesso em: 08 set. 2021.

21 CARVALHO Matheus. Manual de Direito Administrativo. $5^{a}$ Edição. Salvador: Juspodivm. 2018.

22 DE ARAGÃO, Alexandre Santos. Curso de Direito Administrativo, $2^{a}$ ed. Rio de Janeiro: FORENSE, 2013, p. 719.

23 DI PIETRO, Maria Sylvia Zanella.Direito Administrativo, 26ª Edição, São Paulo: ATLAS, 2013, p. 938.
} 
ção por parte da população ${ }^{24}$. Ainda sobre esse escopo insere-se, também, o Princípio da Transparência que, associado à publicidade, são pilares nas licitações e no Estado Democrático de Direito ${ }^{25}$.

O Princípio da Igualdade que possui guarida constitucional não apenas no artigo $5^{\circ}$, como também, no artigo 37, inciso XXI no qual estabelece que a Administração deve tratar todos os administrados com igual respeito e consideração - na melhor compreensão Dworkiniana ${ }^{26}$, ofertando-lhes as mesmas condições, sendo vedada a existência de vantagens a algum, que não se estenda aos demais. Essa igualdade, obviamente, não impede a Administração de estabelecer requisitos básicos no instrumento convocatório. Uma vez que durante o instrumento convocatório trata-se de uma igualdade presumida, de expectativa de contratar com a Administração Pública. Podendo ser excluídos os que não possuem os requisitos necessários após a convocação, sem esbarrar no Princípio da Igualdade. O que, de fato, não pode, é haver tratamento diferenciado aos licitantes em razão de questões como domicílio, sede empresarial, natureza dos licitantes, havendo as exceções ${ }^{27}$.

O Princípio da Competitividade está diretamente ligado ao da igualdade, uma vez que todos os licitantes devem ter as mesmas oportunidades de competição, cabendo à Administração Pública proporcionar, por meio de procedimentos adequados, a concorrência entre os licitantes, sem impor óbices para a sua efetivação. Cabe ressaltar que a supracitada igualdade não é plena, uma vez que deverão ser consideradas, no processo licitatório, as questões inerentes à igualdade material, proporcionando aos hipossuficientes — normalmente empresas de pequeno porte e microempresas — , tratamento desigual na medida da desigualdade, a fim de torná-las equivalente às demais, possibilitando, assim, a isonomia e, consequentemente, a competitividade justa, conforme determina o art. 179 da Constituição Federal ${ }^{28}$.

Princípio da Vinculação ao instrumento convocatório pode ser considerado como um meio eficaz responsável por salvaguardar tanto a Administração Pública quanto aos licitantes, uma vez que determina não apenas que o ordenamento designado especificamente para o processo licitatório deva ser seguido pelas partes, mas também que as normativas previamente estabelecidas no edital de convocação para o processo licitatório devem ser seguidas pelo Administrador sob pena de invalidá-lo, inexistindo a possibilidade de mudanças, salvo se para correção de falhas. Situação em que os licitantes deverão obter ciência, além de tempo hábil para adequarem-se a ela, devendo cumprir, fielmente, os parâmetros estabelecidos durante a convocação, sob pena de desclassificação ${ }^{29}$. É um princípio de suma importância, diretamente relacionado ao Princípio da Legalidade e à respectiva aplicação, pois se não forem observadas as regras dispostas na convocação, poderá ocasionar a ilegalidade no processo licitatório ${ }^{30}$.

O Princípio do Julgamento Objetivo, por sua vez, está diretamente relacionado ao Princípio da Vinculação ao Instrumento Convocatório, ao passo que estabelece que o que outrora foi adotado como requisito obrigatório no instrumento convocatório, deve permanecer inalterado, devendo haver objetividade quando do julgamento, no que tange ao desempate quando mais de uma for os licitantes vencedores, afastando, assim, quaisquer possibilidades de favorecimentos pessoais ${ }^{31}$. Contudo, há algumas exigências no processo licitatório que carregam uma carga subjetiva, como é o caso de comprovação de que o licitante já participou de obras similares ao objeto do processo licitatório. Também no que tange à escolha da melhor técnica, por

\footnotetext{
${ }^{24}$ CARVALHO Matheus. Manual de Direito Administrativo. 5a Edição. Salvador: Juspodivm. 2018.

25 OLIVEIRA, Rafael Carvalho Rezende. Curso de Direito Administrativo. 9a Edição, Rio de Janeiro: MÉTODO, 2021.

${ }^{26}$ Conforme DWORKIN, Ronald. Levando os Direitos a Sério. 3a. ed. São Paulo: Martins Fontes, 2010.

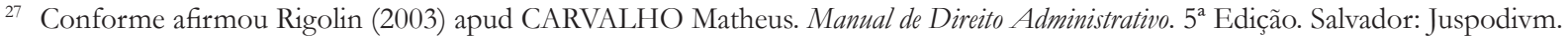
2018.

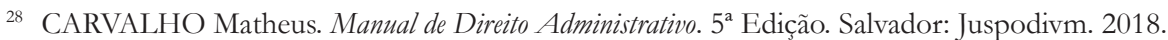

29 CARVALHO Matheus. Manual de Direito Administrativo. $5^{\text {a }}$ Edição. Salvador: Juspodivm. 2018.

30 OLIVEIRA, Rafael Carvalho Rezende. Curso de Direito Administrativo. 9a Edição, Rio de Janeiro: MÉTODO, 2021.

31 CARVALHO Matheus. Manual de Direito Administrativo. 5a Edição. Salvador: Juspodivm. 2018.
} 
isso essas exigências somente podem ser adotadas quando forem extremamente importantes para o objeto licitado ${ }^{32}$.

Ademais, há alguns princípios correlatos aos principais supracitados, sendo eles: Princípio da Indistinção que também está relacionado ao Princípio da Isonomia, ao passo que não se permite a criação de distinções no que tange ao domicílio, naturalidade e sede, conforme art. 3o, $\int 1^{\circ}$, I, do Estatuto), além do art. 19, III da Constituição Federal. Princípio da Inalterabilidade do edital que está diretamente ligado ao Princípio da Publicidade e da Vinculação do Instrumento Convocatório, ao passo que, uma vez publicado o edital, não poderá haver mudanças quanto às regras estabelecidas pela administração pública ${ }^{33}$.

O Princípio do Planejamento — uma das inovações trazidas pela lei n. ${ }^{0}$ 14.133/2021 — está diretamente relacionado ao Princípio da Eficiência, pois pressupõe a realização de estudo técnico anterior à etapa da licitação, já que é destinado para a análise minuciosa das questões que envolvem o objeto, a necessidade, a viabilidade técnica e econômica da licitação e da própria contratação. Já o Princípio do Procedimento Formal relaciona-se ao fato de que os procedimentos licitatórios utilizados deverão seguir os dispositivos normativos, instaurando-se procedimento específico para tanto. Aqui se observam os critérios da moderação, já que se pode abrir espaço para exceções quando não se tratar de algo que possa colocar em xeque a isonomia, sendo, portanto, estabelecidas exceções no artigo 12 da lei n. ${ }^{\circ}$ 14.133/2021 ${ }^{34}$.

O Princípio do Sigilo da proposta, que está relacionado com o Princípio da Moralidade e Igualdade, em que as propostas ofertadas pelos licitantes deverão ser sigilosas por meio de lacres, somente podendo ser abertas em momento oportuno, como em sessão pública previamente agendada, conforme artigo $43 \rrbracket 1^{\circ}$; o Princípio do Formalismo Procedimental estabelece que as regras procedimentais para o processo licitatório devam ir de encontro com as estipuladas em instrumento normativo, não podendo ser alterados, devendo ser observado o devido processo legal e o Princípio da Adjudicação compulsória que estabelece que se, após o certame licitatório, a administração pública quiser contratar, será com o vencedor do processo. O que não corresponde que o vencedor tenha direito subjetivo, mas que se aquilo a Administração fizer, este será o detentor do direito ${ }^{35}$.

O Princípio da Eficiência relaciona-se ao Princípio da Celeridade e Economicidade. Esse princípio está constantemente presente na nova lei de licitações, sendo permitido, em alguns casos, a remuneração variável de acordo com o desempenho das funções, se disposto no edital. No artigo 22 da lei, também há referência à gestão de riscos, devendo ser estabelecido previamente o que couber a cada parte. Por fim, o Princípio da Segregação das Funções, por sua vez, pauta-se na separação e especialização das funções a fim evitar o surgimento de conflitos de interesses entre os agentes, garantindo, assim, a eficiência e consequentemente, a moralidade ${ }^{36}$.

Diante do supramencionado, é perceptível que o programa de Compliance é extremamente compatível com os princípios balizadores da Administração Pública, bem como, os demais dispostos no rol exemplificativo no artigo $5^{\circ}$ da Lei n. ${ }^{\circ} 14.133 / 2021$. Isso, pois, ao buscar a prevenção, redução e mitigação das práticas ímprobas, consagra a moralidade, a legalidade, a eficiência e os demais princípios a esses correlatos. Além disso, em relação ao fato de que as empresas que possuem uma política de compliance devam seguir as normativas dispostas no (sub)ordenamento jurídico ${ }^{37}$, torna-se mais fácil a garantia do cumprimento do disposto quando relacionado ao Princípio da Vinculação ao instrumento convocatório e os que dele decorrem como

\footnotetext{
32 DE ARAGÃO, Alexandre Santos. Curso de Direito Administrativo, 2a ed. Rio de Janeiro: FORENSE, 2013, p. 719.

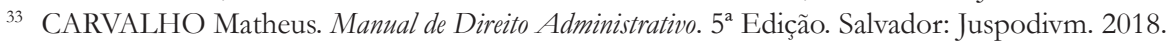

34 OLIVEIRA, Rafael Carvalho Rezende. Curso de Direito Administrativo. 9a Edição, Rio de Janeiro: MÉTODO, 2021.

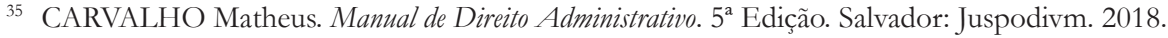

36 OLIVEIRA, Rafael Carvalho Rezende. Curso de Direito Administrativo. 9a Edição, Rio de Janeiro: MÉTODO, 2021.

37 WITTMANN, Cristian Ricardo. Programas de cumprimento (Compliance Programs) e o Direito na sociedade global: A concepção de um campo autônomo de regulação das nanotecnologias em usos militares. Tese: Programa de Pós-Graduação Em Direito - Doutorado Linha De Pesquisa: Sociedade, Novos Direitos E Transnacionalização, São Leopoldo, 2015. Disponível em: http://www.repositorio. jesuita.org.br/handle/UNISINOS/6257 Acesso em: 12 jul. 2021.
} 
o do julgamento objetivo. Contudo, para que sejam atendidos os princípios da igualdade entre os licitantes, da competitividade e os que a ele estão relacionados, faz-se necessário pensar em quais etapas o programa de compliance pode ser exigido. O que pressupõe um conhecimento prévio das etapas do processo licitatório.

Conforme a lei n. ${ }^{\circ}$ 14.133/2021, o processo de licitação é dividido em etapas internas e externas. Dessa forma, enquanto etapa interna, considera-se a fase de preparação para o processo licitatório e etapa externa todos os atos a posteriori, que ocorrem a partir da publicação do edital, o qual funcionará como uma espécie de lei interna da legislação já que delimitará as regras a serem cumpridas pelos licitantes e pela própria Administração Pública. Ressalta-se que a nova lei de licitações estabelece que, em se tratando de procedimentos licitatórios de grande porte, deverá ser exigido, no edital, a implementação de um programa de integridade para o licitante que vencer a licitação, possuindo um prazo de seis meses para tanto, a partir da celebração do contrato, havendo penalidades caso não seja implementado esse mecanismo ${ }^{38}$, conforme o disposto no artigo 25 da lei:

Art. 25. O edital deverá conter o objeto da licitação e as regras relativas à convocação, ao julgamento, à habilitação, aos recursos e às penalidades da licitação, à fiscalização e à gestão do contrato, à entrega do objeto e às condições de pagamento.

$\int 1^{\circ}$ Sempre que o objeto permitir, a Administração adotará minutas padronizadas de edital e de contrato com cláusulas uniformes.

$\int 2^{\circ}$ Desde que, conforme demonstrado em estudo técnico preliminar, não sejam causados prejuízos à competitividade do processo licitatório e à eficiência do respectivo contrato, o edital poderá prever a utilização de mão de obra, materiais, tecnologias e matérias-primas existentes no local da execução, conservação e operação do bem, serviço ou obra.

$\int 3^{\circ}$ Todos os elementos do edital, incluídos minuta de contrato, termos de referência, anteprojeto, projetos e outros anexos, deverão ser divulgados em sítio eletrônico oficial na mesma data de divulgação do edital, sem necessidade de registro ou de identificação para acesso.

$\int 4^{\circ}$ Nas contratações de obras, serviços e fornecimentos de grande vulto, o edital deverá prever a obrigatoriedade de implantação de programa de integridade pelo licitante vencedor, no prazo de 6 (seis) meses, contado da celebração do contrato, conforme regulamento que disporá sobre as medidas a serem adotadas, a forma de comprovação e as penalidades pelo seu descumprimento ${ }^{39}$ (grifo nosso).

Não é uma inovação a adaptação do contexto normativo licitatório com vistas a adotar novas sinergias com demandas sociais como é o caso da noção de desenvolvimento já desenvolvido ${ }^{40}$. A nova lei de licitações é assertiva ao estabelecer a exigência de adoção de um programa de integridade apenas após a contratação. Isso porque permite que princípios basilares do procedimento mantenham-se intactos, como o da livre concorrência, da isonomia e os deles decorrentes. Permitindo que todas as empresas - inclusive aquelas que não possuem um programa de integridade implementado - participem em igualdade de condições do processo. Contudo, há de se problematizar algumas questões que vêm à tona em relação à exigência de adoção desses programas. Pois sabe-se que os programas de integridade dependem da construção de uma cultura delineada na ética, já que envolve não apenas o ambiente organizacional e os respectivos trabalhadores, mas também os colaboradores externos.

Dessa forma, exigir uma plena adequação - e consequentemente, uma grande mudança cultural organizacional - é extremamente complicado. Além disso, é imperioso questionar porque se exige a adoção desses programas apenas para os procedimentos de grande vulto? Considerar que somente nesses casos faz-se necessário a adoção de condutas probas é tornar as práticas corruptas nos procedimentos de menor escala enquanto insignificantes. O referido contexto é problemático, especialmente diante de programas que, para

\footnotetext{
38 OLIVEIRA, Rafael Carvalho Rezende. Curso de Direito Administrativo. 9a Edição, Rio de Janeiro: MÉTODO, 2021.

39 BRASIL. Lei n. ${ }^{\circ}$ 14.133, de $1^{\circ}$ de abril de 2021: Lei de Licitações e Contratos Administrativos. Disponível em: http://www. planalto.gov.br/ccivil_03/_ato2019-2022/2021/lei/L14133.htm. Acesso em: 20 ago. 2021.

${ }^{40}$ Cf. FERREIRA, Felipe Furtado; POTTUMATI, Eduardo Carlos. A licitação como instrumento de desenvolvimento na perspectiva do paternalismo libertário. Revista Brasileira de Políticas Públicas, Brasília, volume 4, n. 1, jan-jun 2014, pp 201-213.
} 
haver um pleno funcionamento, necessitam de alterações significativas nos padrões culturais organizacionais. Isso posto, vale ressaltar que a mera adoção de um programa de integridade no prazo estabelecido, para apenas alguns, não resolve os problemas relacionados à corrupção, incorrendo-se no risco de haver a criação em massa de programas de integridade de fachada.

Dando seguimento às etapas do processo licitatório, após a divulgação do edital, dá-se início à abertura dos envelopes contendo as propostas dos licitantes. A legislação anterior previa a habilitação como procedimento posterior ao julgamento das propostas. Contudo, essa sequência fornece base para discussões de questões formais que, às vezes, prejudicam a celeridade do processo. Dessa forma, a lei n. ${ }^{\text {1 } 14.133 / 2021}$ adotou o julgamento das propostas anteriores à fase de habilitação ${ }^{41}$. O julgamento destina-se à análise das (ir)regularidades, tanto formais quanto materiais, das propostas feitas pelos licitantes. Os critérios a serem utilizados nesse julgamento seguirão o disposto no edital, respeitando os princípios da isonomia, da ampla concorrência, da impessoalidade, dentre outros. Caso haja empate entre as propostas das empresas licitantes, o último critério de desempate a ser valorizado o fato de o licitante possuir um programa de integridade ${ }^{42}$, conforme dispõe o artigo 60 da nova lei de licitações:

Art. 60. Em caso de empate entre duas ou mais propostas, serão utilizados os seguintes critérios de desempate, nesta ordem:

I - disputa final, hipótese em que os licitantes empatados poderão apresentar nova proposta em ato contínuo à classificação;

II - avaliação do desempenho contratual prévio dos licitantes, para a qual deverão preferencialmente ser utilizados registros cadastrais para efeito de atesto de cumprimento de obrigações previstos nesta Lei;

III - desenvolvimento pelo licitante de ações de equidade entre homens e mulheres no ambiente de trabalho, conforme regulamento;

IV - desenvolvimento pelo licitante de programa de integridade, conforme orientações dos órgãos de controle ${ }^{43}$ (grifo nosso).

Aqui, destaca-se o fato de que o legislador, ao estabelecer a utilização do programa de integridade como um dos critérios de desempate, reconhecer a importância social que tal instituto possui. Essa situação qualifica, de fato, o processo licitatório em comparação à antiga legislação — que estabelecia, enquanto critério de desempate, a utilização de sorteio. Contudo, ainda se deve questionar se o fato de reconhecer a utilização dos programas de integridade como mero critério de desempate basta para qualificar o processo licitatório? Ou se um processo licitatório qualificado deve pressupor um empate? Dessa forma, faz-se necessário (re) discutir as formas de (re)inserção de critérios que possam qualificar a contratação pública como um todo e não apenas nos casos em que houver empate.

Posteriormente ao julgamento das propostas, a lei n. ${ }^{0}$ 14.133/2021 traz a etapa da habilitação. Aqui, a Administração Pública verificará a capacidade jurídicas; técnica; fiscal, social e trabalhista e econômico-financeira do licitante. Será adquirida ciência da documentação enviada pelo licitante classificado em primeiro lugar. A fase da habilitação é destinada para a análise da idoneidade e aptidão do potencial contratante com o Erário. Nessa etapa, somente podem ser exigidos os documentos dispostos no artigo $62^{44}$ da nova lei de licitações, sob pena de ferir princípios que constituem o procedimento licitatório como o da isonomia ${ }^{45}$, da

\footnotetext{
${ }_{41}$ OLIVEIRA, Rafael Carvalho Rezende. Curso de Direito Administrativo. $9^{\text {a }}$ Edição, Rio de Janeiro: MÉTODO, 2021.

42 CARVALHO Matheus. Manual de Direito Administrativo. $9^{\text {a }}$ Edição. Salvador: Juspodivm. 2021

43 BRASIL. Lei n. ${ }^{\circ}$ 14.133, de $1^{\circ}$ de abril de 2021: Lei de Licitações e Contratos Administrativos. Disponível em: http://www. planalto.gov.br/ccivil_03/_ato2019-2022/2021/lei/L14133.htm. Acesso em: 20 ago. 2021.

44 A nova lei de licitações estabelece que "Art. 62. A habilitação é a fase da licitação em que se verifica o conjunto de informações e documentos necessários e suficientes para demonstrar a capacidade do licitante de realizar o objeto da licitação, dividindo-se em: I - jurídica; II - técnica; III - fiscal, social e trabalhista; IV - econômico-financeira.” BRASIL. Lei n. ${ }^{\circ} 14.133$, de $1^{\circ}$ de abril de 2021 : Lei de Licitações e Contratos Administrativos. Disponível em: http://www.planalto.gov.br/ccivil_03/_ato2019-2022/2021/lei/ L14133.htm. Acesso em: 20 ago. 2021.

45 CARVALHO Matheus. Manual de Direito Administrativo. 9ª Edição. Salvador: Juspodivm. 2021.
} 
vinculação do instrumento convocatório, dentre outros deles decorrentes. Com a entrada em vigor da nova legislação, essa fase é destinada, apenas, ao licitante vencedor, exceto se essa etapa de habilitação seguir o procedimento antigo e ocorrer antes do julgamento ${ }^{46}$.

Após a finalização dos prazos para os recursos referentes à habilitação, a Autoridade Superior poderá, conforme o artigo 71 da nova lei de licitações exigir que os autos retornem para resolver as possíveis irregularidade ou anular o procedimento, caso essas irregularidades sejam insanáveis; revogar a licitação conforme conveniência e oportunidade ou proceder a adjudicação e homologação da licitação ${ }^{47}$.

Essas novas possibilidades de atuação frente aos atos que apresentem vícios e a possibilidade de saná-los demonstra a busca do legislador em prezar por um procedimento pautado na legalidade e conformidade. Posteriormente, ocorre a etapa da adjudicação e da homologação. Nessa respectiva ordem, o que até então não estava expresso na antiga legislação. É na adjudicação que ocorre a atribuição do objeto da licitação para o vencedor. Já na homologação, a Administração Pública comprova o interesse na contratação ${ }^{48}$.

Diante do supramencionado, verifica-se o reconhecimento por parte da Administração Pública da importância de exigência de programas de conformidade por parte das organizações licitantes como forma de qualificar o procedimento. Contudo, faz-se necessário questionar a forma e o momento pelos quais esses programas são exigidos, já que não se trata de uma simples implementação formal, uma vez que são políticas que exigem uma (trans)formação da cultura organizacional como um todo, o que impossibilita uma implementação efetiva. Dessa forma, devem-se buscar alternativas que evitem a criação de programas de integridade de fachada para que haja uma busca efetiva pelo combate e prevenção da corrupção. Nesse sentido, o próximo tópico será destinado para fazer essa necessária discussão.

Ressalta-se para a possibilidade da exigência de um programa de compliance por parte da administração pública como forma de incentivo e fomento para os sistemas organizacionais como um todo. Ademais à obrigação imposta no art. 174 da Constituição Federal, o Estado, com base nas suas funções de maior centralidade no sistema jurídico, tem melhor capacidade de indicar padrões a serem seguidos pelas organizações do seu entorno. Teubner ${ }^{49}$ entende, sociologicamente, a retroalimentação entre os atores no fomento de normas sistêmicas não mais exclusivas por parte do ente Estatal — tais quais os programas de integridade.

\section{Momento da exigibilidade da adoção de política de compliance anticorrupção para contratar com a administração pública}

Antes da entrada em vigor da lei n. ${ }^{\circ}$ 14.133/2021, algumas legislações estaduais já previam a utilização de programas de integridade como forma de qualificar o processo licitatório. Dentre elas, destaca-se para o Estado do Rio de Janeiro, por meio da lei n. ${ }^{\circ}$ 7.753/2017, que passou a exigir a adoção de programas de integridade - em alguns casos específicos - com o objetivo de proteger a Administração Pública Estadual dos possíveis atos ímprobos que pudessem causar prejuízos de cunho financeiro ao Erário Estadual no mo-

46 CARVALHO Matheus. Manual de Direito Administrativo. 9ª Edição. Salvador: Juspodivm. 2021.

47 BRASIL. Lei n. ${ }^{\circ}$ 14.133, de $1^{\circ}$ de abril de 2021: Lei de Licitações e Contratos Administrativos. Disponível em: http://www. planalto.gov.br/ccivil_03/_ato2019-2022/2021/lei/L14133.htm. Acesso em: 20 ago. 2021.

48 OLIVEIRA, Rafael Carvalho Rezende. Curso de Direito Administrativo. 9a Edição, Rio de Janeiro: MÉTODO, 2021.

49 TEUBNER, Gunther. A Bukowina Global sobre a emergência de um pluralismo jurídico transnacional. Revista Impulso, Piracicaba, v. 13, n. 33, p. 9-31, 2003, p. 11. 
mento da contratação, reduzindo, assim, os possíveis riscos e proporcionando uma maior qualidade para o procedimento $^{50}$. Nesse mesmo sentido, entrou em vigor a lei n. ${ }^{\circ}$ 6308/2019 adotado pelo Distrito Federal ${ }^{51}$.

É de se ressaltar que ambas as legislações — tanto a do Rio de Janeiro quanto a do Distrito Federal — adotaram valores específicos e espécies de contratação em que passou a ser exigida a adoção de um programa de integridade. Situação que não ocorreu nos momentos em que a lei n. ${ }^{0}$ 14.133/2021 faz a exigência, deixando a cargo da livre interpretação das pessoas envolvidas com o processo licitatório, o que significa uma contratação de grande vulto. Isso passa a ser considerado enquanto um problema com base no momento em que deixa de haver um critério exato específico e passa-se a depender de interpretações, já que "grande vulto" poderá possuir proporções diferentes, a depender de quem estiver regulando o processo.

Diante disso, existem diversas especulações dos momentos oportunos para que sejam postos em prática as exigências dos programas de compliance. Algumas correntes afirmam que o ideal da exigibilidade de um programa de integridade por parte da Administração Pública seja no momento do julgamento das propostas, atribuindo pontuações específicas àqueles que possuem os programas de integridade na constituição empresarial ${ }^{52}$. Contudo, acredita-se não ser o momento ideal, pois as modalidades não estão unificadas, existindo vários critérios de julgamento da proposta mais vantajosa para a Administração Pública. Portanto, restringir a um tipo específico a possibilidade de exigência de compliance seria limitar as oportunidades e os tipos de licitações nos quais este estaria presente, não resolvendo, assim, os problemas sistêmicos referentes à prática de atos corruptos.

Ademais, considerando que a etapa de julgamento passa a ser uma das primeiras fases do procedimento licitatório, exigir um programa de integridade já nesse período seria inexequível, pois seria impossível uma análise efetiva referente à eficácia dos programas dos licitantes por parte da Administração Pública, além de que as empresas que não possuem programa de conformidade sairiam em desvantagem em comparação às que possuem, o que de fato, iria impor óbices à efetivação dos princípios inerentes do processo licitatório como o da isonomia e da competitividade entre os licitantes ${ }^{53}$.

No que tange ao último critério de desempate que a lei n. ${ }^{\circ}$ 14.133/2021 estabelece ao considerar as empresas que possuam um programa de integridade, deve-se atentar para que a implementação das políticas de compliance não fiquem restritas a casos de desempate se o objetivo é combater e/ou prevenir a corrupção. Dessa forma, embora seja relevante a adoção desse critério, diante dessa possível forma de fomento público, acredita-se que há outras maneiras de fomentar e até mesmo de exigir a adoção de programas de compliance se o objetivo for proporcionar uma maior segurança orçamentária e administrativa para as contratações públicas.

O que compreende também, a necessidade de (re)pensar se os programas de integridade são importantes apenas nos casos de licitações vultuosas. Pois, ao fazer essa exigência, a legislação desconsidera a importância da probidade no âmbito das contratações públicas que versem sobre valores menores. E, especialmente diante de uma política em que para que haja uma efetividade plena, faz-se necessária a implementação de uma cultura organizacional, torna-se contraditório exigir a probidade de alguns enquanto que de outros não. Dessa forma, esse tipo de exigência é extremamente contraproducente, pois impossibilita a construção de

\footnotetext{
${ }^{50}$ RIO DE JANEIRO. Lei n. ${ }^{\circ}$ 7.753, de 17 de outubro de 2017. Dispõe sobre a instituição do programa de integridade nas empresas que contratarem com a administração pública do Estado do Rio de Janeiro e dá outras providências. Diário Oficial do Estado do Rio de Janeiro, 18 out. 2017.

51 DISTRITO FEDERAL. Lei n. ${ }^{\circ}$ 6.308, de 06 de fevereiro de 2019. Dispõe sobre a implementação de Programa de Integridade em pessoas jurídicas que firmem relação contratual de qualquer natureza com a administração pública do Distrito Federal em todas as esferas de poder e dá outras providências. Diário Oficial do Estado do Distrito Federal, 14 jun. 2019.

52 Segundo Guimarães; Requi (2018) apud ARARIPE, Cíntia Muniz Rebouças de Alencar; MACHADO, Raquel Cavalcanti Ramos. Os programas de integridade para contratação com a administração pública estadual: nudge ou obrigação legal? Um olhar sobre as duas perspectivas. Revista Brasileira de Políticas Públicas, v. 8, n. 2, p. 385-404, 2018.

53 SCHRAMM, Fernanda Santos. O compliance como instrumento de combate à corrupção no âmbito das contratações pública. 2018. Disponível em: https://repositorio.ufsc.br/handle/123456789/190091 Acesso em: 27 jul. 2021.
} 
uma cultura empresarial calcada na ética, já que esta passa a ser exigida apenas para algumas organizações, quebrando o Princípio da Isonomia e da Livre Concorrência, mesmo que, implicitamente, embora — nesse caso - as empresas de grande porte não concorrerão diretamente com as de menor tamanho.

E, diante da impossibilidade de construção de uma cultura organizacional que se paute na ética, enfrenta-se o problema da possibilidade de ineficiência das implementações dos programas de integridade e, consequentemente, da exigência. Pois, até para que a aplicação seja plena, deve ser exigido de forma correta. Especialmente porque, ao considerar que esse tipo de política de integridade se delineia em uma construção coletiva, faz-se necessário que seja exigido coletivamente, sob pena de não haver a assimilação cultural e a consequente aplicação de programas de integridade de fachada, que não possuam efetividade para resolver ou minimizar os problemas relacionados à corrupção.

Dessa forma, destaca-se o grande problema dos programas que são criados apenas para atender exigências estabelecidas, ou simplesmente para atenuar o quadro empresarial em situações de possíveis condenações, sem qualquer interesse na manutenção efetiva do programa para a empresa. Pois a mera existência formal de um programa de integridade não garante a moralidade empresarial, dado que, para a efetividade do compliance, faz-se necessária a existência de um comprometimento significativo por parte de toda a instituição, iniciando pela Alta Administração e perfazendo-se sobre todos os funcionários, construindo assim, uma cultura empresarial calcada em bases principiológicas éticas, probas e morais. Portanto, devem existir medidas especializadas a fim de que haja a implementação efetiva do programa por parte da empresa ${ }^{54}$.

Diante desse quadro, alguns especialistas criticam a exigência de um programa de conformidade para contratar com a Administração Pública, pois há o problema da criação desses programas de fachada, passando a existir, apenas, no âmbito empresarial formal, para efetivar a contratação com a Administração Pública, mas sem funcionar no ponto de vista material. Entretanto, é para esse tipo de caso que existem os programas, já implementados pela Controladoria Geral da União, de avaliação dos programas de integridade adotados pela empresa, como o Pró Ética ${ }^{555}$, que, embora necessite da voluntariedade da empresa em submeter-se à avaliação, com a exigência da existência dos programas de integridade para contratar com a Administração Pública, deveria ser primordial à submissão a essa avaliação, justamente para forçar as empresas a adotarem um programa de compliance efetivo, e não apenas para efetivar os contratos públicos ou atenuar as possíveis punições. Contudo, tais circunstâncias exigem um maior preparo do Estado para a ampliação das avaliações, por meio de servidores capacitados e dotados também de uma conduta ética.

Diante da necessidade de exigência de implementação do programa de compliance anticorrupção e os problemas fiscalizatórios supracitados, que ficariam a cargo unicamente do Estado, pesquisadores possuem algumas sugestões a fim de garantir a efetividade das avaliações dos programas de integridade dentro das empresas. A primeira alternativa, diz respeito à criação de uma agência anticorrupção, conforme já fora criada na Europa. Contudo, essa alternativa ainda é bastante difícil de implementar do ponto de vista prático,

\footnotetext{
${ }^{54}$ CONSELHO ADMINISTRATIVO DE DEFESA ECONÔMICA. Guia para Programas de Compliance. 2016. Disponível em: http://www.cade.gov.br/acesso-ainformacao/publicacoes-institucionais/guias_do_Cade/guia-compliance-versao-oficial.pdf Acesso em: 10 set. 2020.

55 ARARIPE, Cíntia Muniz Rebouças de Alencar; MACHADO, Raquel Cavalcanti Ramos. Os programas de integridade para contratação com a administração pública estadual: nudge ou obrigação legal? Um olhar sobre as duas perspectivas. Revista Brasileira de Políticas Públicas, v. 8, n. 2, p. 385-404, 2018.

${ }^{56}$ O Programa Pró-Ética, supramencionado, é realizado pela Controladoria Geral da União anualmente, em que se divulgam as melhores técnicas de integridade observadas no decorrer do ano. Fomentando, assim, a publicidade das empresas que trabalham no combate aos atos ilícitos, possibilitando o conhecimento público e notório. O que colabora para uma publicidade positiva do setor empresarial, visto que será disponibilizada a marca Pró-Ética. Além disso, é feita uma análise minuciosa do programa de integridade da empresa, por profissionais especializados, que apontarão os pontos positivos e as fragilidades empresariais, contribuindo para melhorias na política de integridade e consequentemente para a atuação da empresa no combate às práticas corruptas, conforme o MINISTÉRIO DA TRANSPARÊNCIA E CONTROLADORIA-GERAL DA UNIÃO - CGU. Manual para implementação de programas de integridade - orientações para o setor público. 2017. Disponível em: https://cgu.gov.br/Publicacoes/etica-e-integridade/arquivos/ manual_profip.pdf Acesso em: 27 set. 2020.
} 
uma vez que essa criação e plena efetivação exige um capital financeiro plausível para iniciar os trabalhos, contratar profissionais especializados, além de todo o processo de instituição de uma nova agência ${ }^{57}$. De outra banda, seria menos dispendioso a atribuição dessa competência fiscalizatória a uma instituição já estabelecida, bem estruturada e dotada da experiência necessária no que tange a esse processo de fiscalização, como o Conselho Administrativo de Defesa Econômica ${ }^{58}$.

Todavia, apesar das ressalvas quanto ao tipo de contratação em que é exigido o programa de integridade na nova lei de licitações e as possíveis problemáticas existentes, considera-se oportuno o momento em que o instituto é exigido. Não sendo estabelecido como condicionante de análise das propostas, mas como uma obrigação correspondente ao momento posterior da homologação e assinatura do contrato pelo licitante vencedor. Ou seja, trata-se de uma obrigação contratual do licitante vencedor, incidindo, apenas, em sanção contratual o descumprimento após decorrido o prazo estipulado na legislação.

Acredita-se, portanto, que esse é o melhor momento para ser exigida uma política de integridade, uma vez que não acarreta em diferenciações entre os licitantes no decorrer dos procedimentos que envolvem a competição, sendo todos os licitantes julgados pela Comissão de licitação de maneira isonômica, possibilitando à Administração Pública a escolha da proposta mais vantajosa efetivamente, uma vez que os únicos critérios a serem julgados serão aquelas estipuladas no momento do julgamento, sem diferenciar empresas possuidoras e não possuidoras de uma política de integridade, dando-se, ainda, para a empresa vencedora, prazo previamente estipulado em legislação para adotar o programa e estar, literalmente, em conformidade ${ }^{59}$.

Também, não possui guarida a ideia de que as empresas que já possuem o compliance, teriam preferência em detrimento das outras, pois não teriam o custo da implementação do programa. Todavia, no momento de julgamento das propostas, existem outros fatores que também são analisados, como a capacidade técnica, pautando-se, na maioria das vezes, em critérios muito específicos. O que, de fato, não leva a preferência de um licitante em detrimento do outro. O mesmo não aconteceria com a exigência de programas de integrida$\mathrm{de}^{60}$. Além disso, ao estar estabelecido no instrumento convocatório, ou em alguma legislação que verse sobre licitação como as supracitadas, os licitantes já saberão que, se forem os vencedores, deverão possuir uma política de integridade, preparando-se para tanto. Aliás, na atual conjuntura, é de extrema importância que as empresas possuam esses instrumentos de mitigação de riscos, principalmente quando da contratação com a Administração Pública. Ademais, os custos de implementação de compliance serão repassados ao Erário, não considerando como problema para os licitantes, desde que possuam a proposta mais vantajosa a ele ${ }^{61}$.

Portanto, embora existam algumas dificuldades no que tange à aplicação de um programa de compliance nas empresas, devido à falta de incentivos por parte do Estado, acredita-se que a existência de um programa de integridade, enquanto balizador das condutas humanas, tanto nos âmbitos empresariais quanto nos ambientes externos a este, é de extrema importância para coibir e prevenir os atos corruptos. Principalmente, no que tange à contratação com a Administração Pública, pois envolve a sociedade como um todo, dado que os recursos disponíveis do erário são os mesmos delineados para a efetivação dos direitos difusos e garantias individuais. Por isso, atos ilícitos que prejudiquem o Estado prejudicam, também, uma sociedade inteira.

\footnotetext{
57 CONSELHO ADMINISTRATIVO DE DEFESA ECONÔMICA. Guia para Programas de Compliance. 2016. Disponível em: http://www.cade.gov.br/acesso-ainformacao/publicacoes-institucionais/guias_do_Cade/guia-compliance-versao-oficial.pdf Acesso em: 10 set. 2020.

58 COSTA, Gabriela Revoredo Pereira da. Compliance, lei da empresa limpa e lei sapin II: uma análise da aplicação do regime de obrigatoriedade de adoção de programas de integridade corporativa no Brasil. 2017. Trabalho de Conclusão de Curso. Universidade Federal do Rio Grande do Norte. Disponível em: https://monografias.ufrn.br/jspui/bitstream/123456789/5659/1/GabrielaRPC_Monografia.pdf Acesso em: 08 set. 2021.

59 PIROTINI, Rodrigo Exigência de compliance nas contratações com o poder público é constitucional. 2018. Disponível em: https://www. conjur.com.br/2018-dez-03/pironticonstitucional-exigir-compliance-contratacoes-publicas Acesso em 23 nov. 2019.

60 PIROTINI, Rodrigo Exigência de compliance nas contrataçôes com o poder público é constitucional. 2018. Disponível em: https://www. conjur.com.br/2018-dez-03/pironticonstitucional-exigir-compliance-contratacoes-publicas Acesso em 23 nov. 2019.

${ }^{61}$ SCHRAMM, Fernanda Santos. O compliance como instrumento de combate à corrupção no âmbito das contratações pública. 2018. Disponível em: https://repositorio.ufsc.br/handle/123456789/190091 Acesso em: 27 jul. 2021.
} 
Diante desse quadro, nota-se a importância de instrumentos que balizem as condutas empresariais por meio do poder de polícia do Estado e da força normativa.

\section{Considerações finais}

Em suma, conclui-se que a exigência de um programa de compliance por parte da Administração Pública, para as empresas licitantes, é um importante direcionamento para a qualificação do processo licitatório, uma vez que a existência de um programa efetivo de integridade é capaz de buscar a prevenção e mitigação dos riscos empresariais. Além disso, por meio da construção de uma cultura empresarial calcada em valores éticos e morais, há uma modificação na forma de pensar e agir daqueles que estão envolvidos com o âmbito empresarial, diminuindo a prática de atos ilícitos.

Contudo, ressalta-se a necessidade de revisão e readequação da destinação dessa obrigatoriedade. Pois, ao utilizar critérios subjetivos para a exigência como a vultuosidade, torna essa adoção instável a depender de quem estará organizando o procedimento. Além disso, deve-se mencionar, na problemática existente, ao exigir a adoção dos mecanismos de integridade apenas para as licitações que envolvam essa vultuosidade, uma vez que se trata de mecanismos que para serem instaurados de forma efetiva, faz-se necessária a construção de uma cultura organizacional que abranja não apenas os membros de uma determinada organização, mas todos os que com ela se relacionam externamente.

Dessa forma, ao exigir a adoção de programas de integridade apenas em alguns casos, é desconsiderar a importância que a prevenção e combate à corrupção devam ser buscados em todos os âmbitos, em todas as organizações e em todas as licitações. E, especialmente diante de uma política em que, para que haja uma efetividade plena, faz-se necessária a implementação de uma cultura organizacional, tornando-se contraditório exigir a probidade de alguns enquanto que de outros não. Somente a partir do momento em que a legislação ampliar essa exigência se caminhará para alterações culturais internas e externas à organização, o que acabará com a possibilidade de criação de programas de compliance de fachada para contratar com o poder público.

A partir de então, ressalta-se a importância ainda maior da existência de mecanismos ofertados pelo Estado para a fiscalização e para o controle das atividades, a fim de evitar a criação e o mantimento desses programas de fachada. Garantindo, assim, a efetivação dos benefícios inerentes às políticas de integridade. Ou seja, a existência de um programa de conformidade dentro da órbita institucional, se bem administrado, resultará em uma gestão pautada pela probidade, pela ética e pela moralidade.

Consequentemente, os benefícios supracitados estendem-se ao Erário e a toda sociedade, uma vez que, com base na contratação pública com empresas probas, será possível a obtenção da proposta mais vantajosa para a Administração Pública. Sendo assim, serão ofertados serviços públicos de melhor qualidade à sociedade, ao passo que diminuirão as práticas ilícitas, que, por sua vez, desgastam a máquina pública e impõem óbices à efetivação dos direitos e garantias individuais. Assim, o erário possuirá uma maior transparência no que tange às suas instituições, sendo essa uma necessidade político-econômica na atual conjuntura. O que, de fato, contribuirá para a plena efetivação dos princípios inerentes ao processo licitatório, como a legalidade, impessoalidade, moralidade e publicidade.

No tocante ao momento oportuno a ser exigido o programa de integridade, confirmam-se as hipóteses prelecionadas. Conclui-se que, se a adoção do programa de compliance for exigida durante o momento do julgamento, torna-se contraproducente, pois colocará óbices na efetivação dos princípios do processo licitatório, restringindo a competitividade, ao passo que haverá uma desigualdade notória entre as licitantes que possuem e as que não possuem o programa de integridade. Ao passo que a implementação do compliance 
possui valores altos, além de ser dispendiosa, limitando, assim, as potenciais contratantes com a Administração Pública.

De outra banda, ao levar em consideração os princípios licitatórios, supõe-se que essa exigência é mais eficaz se cobrada apenas na fase da contratação com a Administração Pública, pois as potenciais contratantes já terão a ciência da exigência do compliance, preparando-se para a adoção deste durante o decorrer do processo licitatório. Além disso, no momento da contratação, é estipulado um prazo para a instituição do programa, não infringindo assim em nenhum princípio procedimental.

\section{Referências}

ABBI. Associação Brasileira de Bancos internacionais; FEBRABAN, Federação Brasileira de Bancos. Função de Compliance. 2009. Disponível em: http://www.abbi.com.br/download/funcaodecompliance_09.pdf Acesso em 24 set. 2019.

ALMEIDA NETO, Edemilson Machado. Combate à corrupção: uma análise do acordo de leniência e do programa de Compliance na lei No 12.846/2013. Brasília: Universidade de Brasília - Faculdade de Direito, 2015. Disponível em: http://bdm.unb.br/bitstream/10483/10837/1/2015_EdmilsonMachadodeAlmeidaNeto.pdf Acesso em 03 Abril 2019.

BANCO CENTRAL DO BRASIL. Dispõe sobre a implantação e implementação de sistema de controles internos. Resolução no 2554 de 24 de setembro de 1998. Disponível em: https://www.bcb.gov.br/pre/normativos/res/1998/pdf/res_2554_v2_P.pdf Acesso em 07 jun 2019.

BRAGA, André de Castro. A exigência de programa de integridade em licitações federais. 2018. Disponível em: https://www.conjur.com.br/2018-abr-21/andre-bragaexigencia-programa-integridade-licitacoes Acesso em 23 nov 2019.

BRASIL. Decreto-lei no 3.678, de 30 de novembro de 2000. Promulga a Convenção sobre o Combate da Corrupção de Funcionários Públicos Estrangeiros em Transações Comerciais Internacionais, concluída em Paris, em 17 de dezembro de 1997. Disponível em: http://www.planalto.gov.br/ccivil_03/decreto/D3678. htm Acesso em 15 jun 2019.

BRASIL. Decreto-lei no 4.410, de 07 de outubro de 2002. Promulga a Convenção Interamericana contra a Corrupção, de 29 de março de 1996, com reserva para o art. XI, parágrafo 1o, inciso "c". Disponível em: http://www.planalto.gov.br/ccivil_03/decreto/2002/D4410.htm Acesso em 15 jun 2019.

BRASIL. Decreto-lei no 5.687, de 31 de janeiro de 2006. Promulga a Convenção das Nações Unidas contra a Corrupção, adotada pela Assembléia-Geral das Nações Unidas em 31 de outubro de 2003 e assinada pelo Brasil em 9 de dezembro de 2003. Disponível em: http://www.planalto.gov.br/ccivil_03/_Ato20042006/2006/Decreto/D5687.htm Acesso em 15 jun 2019.

BRASIL. Lei n ${ }^{\circ} 12.846$, de $1^{\circ}$ de agosto de 2013. Dispõe sobre a responsabilização administrativa e civil de pessoas jurídicas pela prática de atos contra a administração pública, nacional ou estrangeira, e dá outras providências. Diário Oficial da União, Brasília, 2 ago. 2013. Disponível em: http://www.planalto.gov.br/ ccivil_03/_ato2011-2014/2013/lei/112846.htm. Acesso em: 15 jun. 2019

BRASIL. Lei no 8.666, de 21 de junho de 1993. Regulamenta o art. 37, inciso XXI, da Constituição Federal, institui normas para licitações e contratos da Administração Pública e dá outras providências. Diário Oficial da União, Brasília, 22 jun. 1993. Disponível em: http://www.planalto.gov.br/ccivil_03/Leis/18666cons. Acesso em: 20 jun. 2019 
BRASIL. Lei n ${ }^{\circ}$ 14.133, de $1^{\circ}$ de abril de 2021: Lei de Licitações e Contratos Administrativos. Disponível em: http://www.planalto.gov.br/ccivil_03/_ato2019-2022/2021/lei/L14133.htm. Acesso em: 20 ago. 2021.

BRASIL. Constituição (1988). Constituição da República Federativa do Brasil. Disponível em: http://www. planalto.gov.br/ccivil_03/constituicao/constituicaocompilado.htm. Acesso em: 12 out. 2019.

BREIER, Ricardo. Implementação de programas de compliance no setor público é um desafio. 2015. Disponível em: https://www.conjur.com.br/2015-ago-20/ricardo-breiercompliance-setor-publico-desafio-pais Acesso em: 14 nov. 2019.

CARVALHO Filho,José dos Santos. Manual de Direito Administrativo. 32ª Edição. São Paulo: Atlas. 2018.

CARVALHO Matheus. Manual de Direito Administrativo. 9ª Edição. Salvador: Juspodivm. 2021.

CARVALHO Matheus. Manual de Direito Administrativo. 5a Edição. Salvador: Juspodivm. 2018.

COLARES, Wilde Cunha. Ética e compliance nas empresas de outsourcing. 2014. Disponível em: http://dspace. insper.edu.br/xmlui/handle/11224/1238 Acesso em: 10 set. 2019.

COSTA, Gabriela Revoredo Pereira da. Compliance, lei da empresa limpa e lei sapin II: uma análise da aplicação do regime de obrigatoriedade de adoção de programas de integridade corporativa no Brasil. 2017. Trabalho de Conclusão de Curso. Universidade Federal do Rio Grande do Norte. Disponível em: https://monografias.ufrn.br/jspui/bitstream/123456789/5659/1/GabrielaRPC_Monografia.pdf Acesso em: 08 set. 2019.

ARARIPE, Cíntia Muniz Rebouças de Alencar; MACHADO, Raquel Cavalcanti Ramos. Os programas de integridade para contratação com a administração pública estadual: nudge ou obrigação legal? Um olhar sobre as duas perspectivas. Revista Brasileira de Políticas Públicas, v. 8, n. 2, p. 385-404, 2018.

DE ARAGÃO, Alexandre Santos. Curso de Direito Administrativo, $2^{\mathrm{a}}$ ed. Rio de Janeiro: FORENSE, 2013, p. 719

DE DEFESA ECONÔMICA, Conselho Administrativo. Guia para Programas de Compliance. 2016. Disponível em: http://www.cade.gov.br/acesso-ainformacao/publicacoes-institucionais/guias_do_Cade/guia-compliance-versao-oficial.pdf Acesso em: 10 set. 2019.

DI PIETRO, Maria Sylvia Zanella.Direito Administrativo, 26a Edição, São Paulo: ATLAS, 2013, p. 938

DISTRITO FEDERAL. Lei ñ 6.308, de 06 de fevereiro de 2019. Dispõe sobre a implementação de Programa de Integridade em pessoas jurídicas que firmem relação contratual de qualquer natureza com a administração pública do Distrito Federal em todas as esferas de poder e dá outras providências. Diário Oficial do Estado do Distrito Federal, 14 jun. 2019.

DOS SANTOS CHAVES, Eber. Aspectos Importantes da Fase Interna da Licitação: uma Análise sobre o Conjunto de Elementos Necessários e Suficientes para a Caracterização do Objeto do Processo Licitatório. Revista Controle: Doutrinas e artigos, v. 13, n. 1, p. 149- 170, 2015. Disponível em: http://revistacontrole.ipc. tce.ce.gov.br/index.php/RCDA/article/view/26 Acesso em: 18 set. 2019.

DOS SANTOS, Jose et al. Manual de Direito Administrativo, 32ª Edição, São Paulo: ATLAS, 2018, p. 1404

DWORKIN, Ronald. Levando os Direitos a Sério. 3a. ed. São Paulo: Martins Fontes, 2010.

FEBRABAN. Guia Boas Práticas de Compliance. 2018. Disponível em: https://cmsportal.febraban.org.br/ Arquivos/documentos/PDF/febraban_manual_compliance_2 018_web.pdf Acesso em: 12 set. 2019. FILHO, Marçal Justen. Comentários à lei de licitações e contratos administrativos, $14^{a}$ ed. São Paulo: DIALÉTICA, 2010, p. 991

FERREIRA, Felipe Furtado; POTTUMATI, Eduardo Carlos. A licitação como instrumento de desenvolvimento na perspectiva do paternalismo libertário. Revista Brasileira de Políticas Públicas, Brasília, volume 4, n. 1, jan-jun 2014, pp 201-213. 
FORTINI, Cristina; MOTTA, Fabrício. Corrupção nas licitações e contratações públicas: sinais de alerta segundo a transparência internacional. Belo Horizonte: A\&C - Revista de Direito Administrativo e Constitucional, 2016, n. 64. Disponível em: http://www.editoraforum.com.br/wp-content/uploads/2016/07/corrupcao-licitacoes.pdf Acesso em 05 Abril 2019.

GABARDO, Emerson et al. A nova lei anticorrupção e a importância do compliance para as empresas que se relacionam com a Administração Pública. A\&C-Revista de Direito Administrativo \& Constitucional, v. 15, n. 60, p. 129-147, 2015. Disponível em: http://www.revistaaec.com/index.php/revistaaec/article/view/55 Acesso em: 10 set. 2019.

GARBACCIO, Grace Ladeira; et all. Startup e o desafio do compliance. Revista Brasileira de Políticas Públicas, Brasília, volume 10, n. 3, dez 2020, pp 329-342.

GARCIA, Sheila Abukater Arkie. Compliance: um instrumento de governança corporativa e fomento do mercado de capitais. 2012. Disponível em: http://dspace.insper.edu.br/xmlui/handle/11224/303 Acesso em: 27 set. 2019.

GERHARDT, Tatiana Engel;SILVEIRA, Denise Tolfo (org.). Métodos de pesquisa. Porto Alegre: Editora da UFRGS, 2009. 120 p.

JORDÃO, Eduardo; COSTA, Luiz Carloss Penner Rodrigues da. Estratégias regulatórias de controle à corrupção. Revista Brasileira de Políticas Públicas, Brasilia, volume 11, n. 1, abr 2021, pp 210-241.

JUNIOR, Mario Engler Pinto. Corrupção, governança, ética e compliance. Revista de Direito da Empresa e dos Negócios, v. 1, n. 1, p. 41-56, 2017. Disponível em: http://revistas.unisinos.br/index.php/rden/article/ view/14292/6019 Acesso em: 27 set. 2019

MINISTÉRIO DA TRANSPARÊNCIA E CONTROLADORIA-GERAL DA UNIÃO - CGU. Mamual para implementação de programas de integridade - diretrizes para empresas privadas. 2015. Disponível em: https:// www.cgu.gov.br/Publicacoes/etica-e-integridade/arquivos/programa-de-integridadediretrizes-para-empresas-privadas.pdf Acesso em: 27 set. 2019.

MINISTÉRIO DA TRANSPARÊNCIA E CONTROLADORIA-GERAL DA UNIÃO - CGU. Manual para implementação de programas de integridade - orientações para o setor público. 2017. Disponível em: https:/ /cgu. gov.br/Publicacoes/etica-e-integridade/arquivos/manual_profip.pdf Acesso em: 27 set. 2019.

MOIR, J. Corporate Governance in Asia: A work in progress. Asialaw, v. 1, 2006.

MOREIRA, Eliane de Oliveira. Compliance no Brasil: Aspectos da responsabilidade fiscal das empresas no combate à corrupção. Paraná: Revista Jurídica da Escola Superior de Advocacia da OAB-PR, 2018, n. 3. Acesso em: 27 jul. 2021.

OLIVA, Milena Donato; DA GUIA SILVA, Rodrigo. Notas sobre o compliance no direito brasileiro. Revista Quaestio Iuris, v. 11, n. 04, p. 2708-2729, 2018. Disponível em: https://www.e-publicacoes.uerj.br/index. php/quaestioiuris/article/view/33843/27065 Acesso em: 29 set. 2019.

OLIVEIRA, Rafael Carvalho Rezende. A Exigência de Programas de Compliance e Integridade nas Contratações Públicas: O Pioneirismo do Estado do Rio de Janeiro e do Distrito Federal. 2019. Disponível em: < http:/ /genjuridico. com.br/2019/04/29/a-exigenciade-programas-de-compliance-e-integridade-nas-contratacoes-publicas-o-pioneirismo-doestado-do-rio-de-janeiro-e-do-distrito-federal/> Acesso em: 27 set. 2019.

OLIVEIRA, Rafael Carvalho Rezende. Curso de Direito Administrativo. $9^{a}$ Edição, Rio de Janeiro: MÉTODO, 2021.

PIROTINI, Rodrigo Exigência de compliance nas contratações com o poder público é constitucional. 2018. Disponível em: https://www.conjur.com.br/2018-dez-03/pironticonstitucional-exigir-compliance-contratacoes-publicas Acesso em 23 nov. 2019. 
PORTAL DE COMPLIANCE. Os 8 Passos de um Programa de Compliance e Etica Empresarial. Disponível em: https://portaldecompliance.com.br/8-passos-para-complianceempresarial Acesso em: 27 set. 2019.

RIBEIRO, Marcia Carla Pereira; DINIZ, Patrícia Dittrich Ferreira. Compliance e lei anticorrupção nas empresas. Paraná: Revista de Informação Legislativa, 2015, n. 205. Disponível em: https://www12.senado.leg.br/ril/ edicoes/52/205/ril_v52_n205_p87.pdf Acesso em 20 maio 2019.

RIO DE JANEIRO. Lei n ${ }^{\circ}$ 7.753, de 17 de outubro de 2017. Dispõe sobre a instituição do programa de integridade nas empresas que contratarem com a administração pública do Estado do Rio de Janeiro e dá outras providências. Diário Oficial do Estado do Rio de Janeiro, 18 out. 2017.

SCHRAMM, Fernanda Santos. O compliance como instrumento de combate à corrup̣cão no âmbito das contratações pública. 2018. Disponível em: https://repositorio.ufsc.br/handle/123456789/190091 Acesso em: 27 set. 2019.

SILVA, Pedro Gabril Kenne da Silva. O papel do controle interno na Administração Pública. Porto Alegre: ConTexto, 2002, v. 2. Disponível em: https://seer.ufrgs.br/ConTexto/article/view/11555/0 Acesso em 15 abril de 2019.

STUTZ, Rosiane Sant'Anna. Compliance e os códigos de ética das empresas de capital aberto no Brasil: uma análise sob a ótica institucionalista. 2017. Tese de Doutorado. Disponível em: https://bibliotecadigital.fgv.br/dspace/ handle/10438/19609 Acesso em: 27 set. 2019.

TEUBNER, Gunther. A Bukowina Global sobre a emergência de um pluralismo jurídico transnacional. Revista Impulso, Piracicaba, v. 13, n. 33, p. 9-31, 2003.

WITTMANN, Cristian. Programas de cumprimento (compliance programs) e o Direito na sociedade global: A concepção de um campo autônomo de regulação das nanotecnologias em usos militares. Tese: Programa de Pós-Graduação em Direito - Doutorado linha de Pesquisa: Sociedade, Novos Direitos E Transnacionalização, São Leopoldo, 2015. Disponível em: http://www.repositorio.jesuita.org.br/handle/UNISINOS/6257 Acesso em: 12 set. 2019.

XAVIER, Christiano Pires Guerra. Programas de compliance anticorrupsão no contexto da lei 12.846/13: ELementos e estudo de caso. Dissertação (Mestrado Profissional em Direito dos Negócios Aplicado e Direito Tributário Aplicado) - FGV - Fundação Getúlio Vargas, São Paulo, 2015. 
Para publicar na revista Brasileira de Políticas Públicas, acesse o endereço eletrônico www.rbpp.uniceub.br

Observe as normas de publicação, para facilitar e agilizar o trabalho de edição. 